\title{
Measurment of High Pressure Gas Adsorption with a Volumetric Apparatust
}

\author{
Sentaro Ozawa and Yoshisada Ogino \\ Department of Chemical Engineering, Faculty of Engineering, Tohoku \\ University; Aramaki Aoba, Sendai-shi, Japan
}

\begin{abstract}
Adsorption isotherms for $\mathrm{N}_{2}, \mathrm{CO}_{2}$ and $\mathrm{SO}_{2}$ on activated carbon, silica gel, and alumina have been measured over wide ranges of pressure and temperature, using a constant volume type adsorption apparatus which is capable of precise adsorption measurement with convenient manipulations at high pressure.

It was found that, under the experimental conditions, amounts of adsorption of $\mathrm{N}_{2}$ and $\mathrm{SO}_{2}$ are increased monotonously with pressure, while an adsorption maximum was observed for $\mathrm{CO}_{2}$.

From the apparent amount of adsorption, the absolute (or true) amount of adsorption was calculated by assuming the equality of the volume of adsorbed phase to the pore volume of of the adsorbent.

Several adsorption equations were examined to fit the absolute adsorption data, and it was found that multilayer type adsorption equation with small $n$-values was applicable to all of the gas-solid systems studied in the present work.
\end{abstract}

† Physical Adsorption of Gases at High Pressures. I.

(日本化学会誌, 1972, p. 8 16)

\section{高压下における気体の吸着量測定と解析 ${ }^{122}$}

1（1971 年 7 月 29 日受理）

小沢 泉太郎・荻 野 義 定*

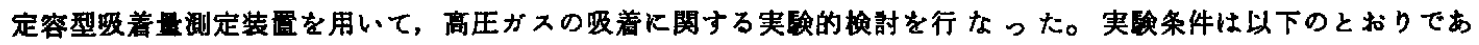

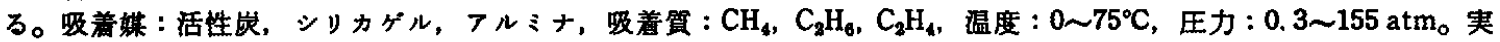



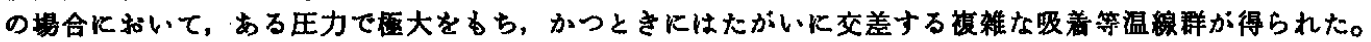


それらは，n-值の小さい多分子層吸着式 (BET 式, Pickett の式) で表現されることがわかった。真の吸着量をよく 表胃する Pickettの式の定数と，吸着媒・唚着質の物性值との間の関係を導き出し，得られた相関係を見かけの吸 着量の推算に使った。 $\mathrm{N}_{2}$ の吸着を除くと，推算した吸着量はかなりよく（約 $20 \%$ の偏美）実測値と一致した。

\section{1 粕}

気体の吸着量を吸着質ならびに吸着媒の基本的な性質に基つい、 て，推算できる上5にすることは，受体の吸着現象の応用を図る 上からす重要なことではなかららかと考えられる。従来,このよ らな目的をすってなされた研究すないわけではないが，それらの 大部分は大気圧以下の吸着の取り扱いに関するむので, その成果 を高圧下の気体の吸着に適用することは困難である。高圧下の気 体の吸着においては，吸着等温線に極大が現われる例がしばしば 認められており,この現象は従来の吸着理論たけけでは説明できな いからである。

1）この報文を“高压ガスの物理吸着に関する研究（第 2 報）” とする.

2). 前報（第 1 報），小沢泉太郎，荻野義定，日化，1972，1.

* 東北大学工学部化学工学科, 仙台市荒巻字青葉
ところで著者らは前報に述べた研究において，高压下における 公素, 二酸化孷素, および二酸化イオウの活性炭, シリカゲル, およびアルミナ上への吸着量を湘定し，その結果を考察した。そ して実測される吸着量，すなわら見かけの吸着最から真の吸着量 を求めるにあたり，吸着相の容皘を吸着媒の細孔容積に等しいと する近似が有效であることを示した。さらに，このようにして求 めた真の吸着量は、試験したどの気体一固体系の場合にも，吸着 層数が大きくない多分子層吸着式で表わされることを示した。

以上のような著者らの研究結果が, もし一般性のあるものであ れば，著者らが前報で提出した取り扱い法は，高圧下に捛ける気 体の吸着量の推算に対し有用な基碟を与えるるのと考えられる。 ただ前報に述べた研究では，試鈳に供した気体は 3 種類だけで， 契験結果の取り报い方法の一般性までは論じられなかった。

以上のような事情を考慮し，本研究では，まず吸着質気体の種 類を豊富にしよらとして、メタン, ェタン,およびェチレンを選 
び,これらの気体の活性炭、シリカゲル，およびアルミナ上への 吸着量を高压下で測定した。そして，この結奥に対し，前報で述 べた解析法が適用できるかどらかを检討しつう，高圧下における 気体の吸着量推算の方法を見いたそうとした。

\section{2 实験}

\section{1 装置および実験方法}

高压下Kおける笑体の吸着量測定には，容積一定の吸着系内の 王力が吸着により減少することを観湘する方式，すなわち定容法 を採用した。この場合，実祭には気体の密度を測定し，P-V - T

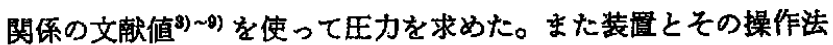
は前報2に記載したと㥂りである。

\section{2 試 料}

吸着媒に用いた活性能、シリカダル，およびアルミナは，前報 に述へた研究に使用したものと同じである。一つの第体一固体系 では同一の吸着媒をくり返し使用し，各実験の前に， $300^{\circ} \mathrm{C}$ にお いて〜10-4 $\mathrm{mmHg}$ の真空下で約 10 時間脱ガスを行なった。ま たメタン, エタンおよびエチレンは，いずれるボンベ入りの市 販品 (99.5\% 以上) であって, シリカゲルを充テンした精製器を 通過させたのちに使用した。

\section{3 結果}

活性炭，シリルゲルおよびアルミナ，それぞれへのメタンの吸 着等温線を図 1〜3 K，エタンの吸着等温線を図 4〜6に，また，

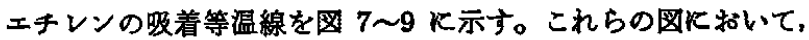

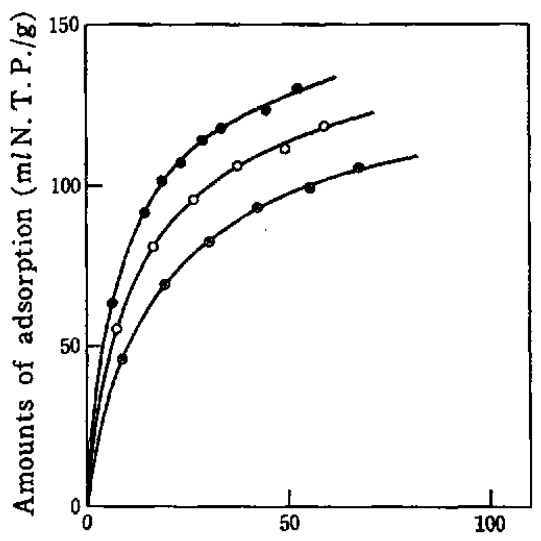

Fugacity (atm)

Fig. 1 Adsorption isotherms for methane-activated carbon system.

$$
\begin{aligned}
& \text { Temp. }\left({ }^{\circ} \mathrm{C}\right)- \\
& \odot: 75, \bigcirc: 50, \bigcirc: 30
\end{aligned}
$$

3) A. Michels, G.W. Nederbragt, Physica, 3, 569(1936).

4) D. R. Douslin, R. H. Harrison, R. T. Moore, J. P. McCullough, J. Chem. Eng. Data, 9, 358(1964).

5) A. Michels, J. de Gruyter, F. Niesen, Physica, 3, 346 (1936).

6) A. Michels, M. Geldermans, ibid., 4, 967(1942).

7) R. York, Jr., E. F. White, Jr., Trans. Amer. Inst. Chem. Eng., 40, 227(1944).

8) J. A. Beattie, C. Hadlock, N. Poffenberger, J. Chem. Phys., 3, 93(1935).

9) J. A. Beattie, G. Su, G. L. Simard, J. Amer. Chem. Soc., $61,926(1939)$.

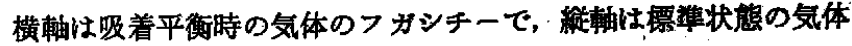
の体颖に換算した平衡吸着量（吸着媒単位重量あたり）である。 一般的にいうと，同一の温度圧力下では，活性拻〉ジシカゲル？

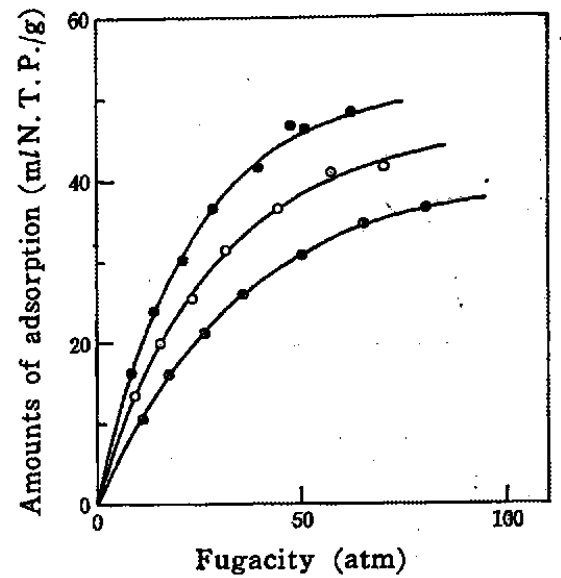

Fig. 2 Adsorption isotherms for methane-silicagel system

Temp. $\left({ }^{\circ} \mathrm{C}\right)$

$\odot: 75, \bigcirc: 50, \bigcirc: 30$

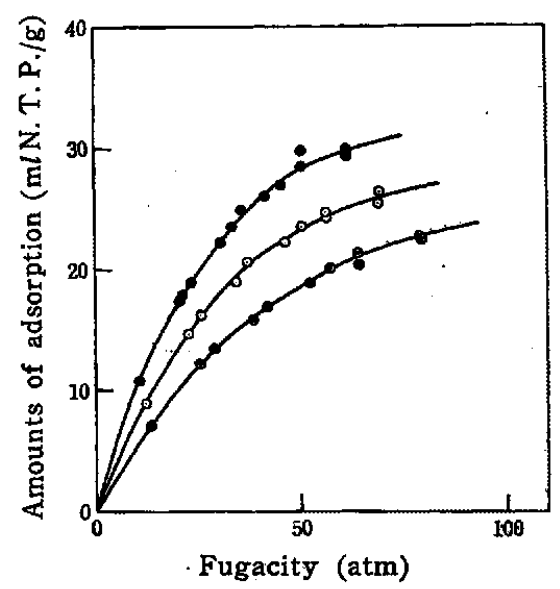

Fig. 3 Adsorption isotherms for methane-alumina system Temp. $\left({ }^{\circ} \mathrm{C}\right)-$

$\odot: 75, \bigcirc: 50$

\section{: $\mathbf{3 0}$}



Fig. 4 Adsorption isotherms for ethane-activated carbon system

Temp. $\left({ }^{\circ} \mathrm{C}\right)$

$$
\odot: 75, \bigcirc: 50, \bigcirc: 25, \text { (1) }: 0
$$




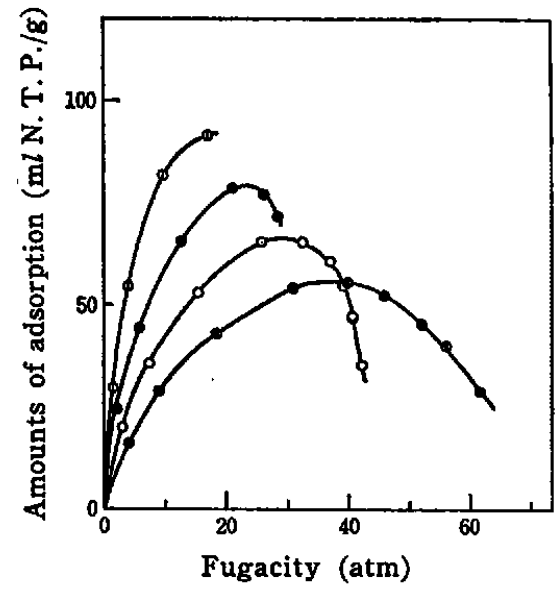

Fig. 5 Adsorption isotherms for ethane-silicagel system

Temp. $\left({ }^{\circ} \mathrm{C}\right)$

$\odot: 75, \bigcirc: 50, \bigcirc: 25,(1): 0$

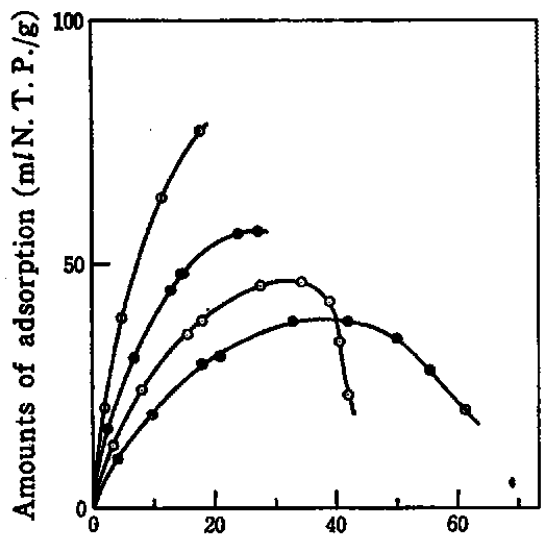

Fugacity (atm)

Fig. 6 Adsorption isotherms for ethane-alumina system
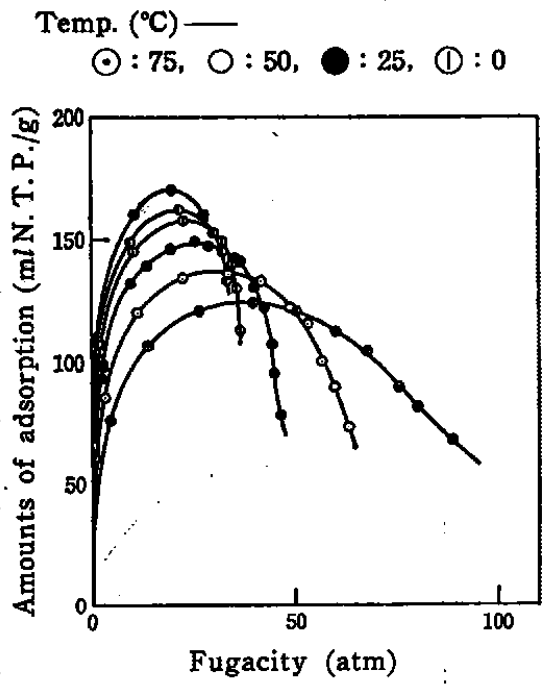

Fig. 7 Adsorption isotherms for ethylene-activated carbon system

Temp. $\left({ }^{\circ} \mathrm{C}\right)-$

$\odot: 75, \bigcirc: 50, \bigcirc: 30,(1): 15, \bigcirc: 9, \oplus: 0$

アルミナの順に吸着量怔なくなっていることが認められたが，

図 4〜9Kみられるように, エタンならびにエチレンの吸着等温 線の大部分には極大が琶められ，乙かす高圧部で吸着等温線が交

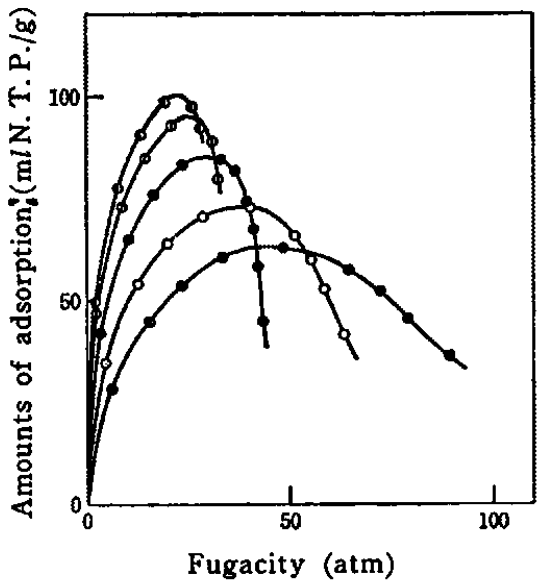

Fig. 8 Adsorption isotherms for ethylene-silicagel system

Temp. $\left({ }^{\circ} \mathrm{C}\right)$

$\odot: 75, \bigcirc: 50, \bigcirc: 25,(1): 9, \varnothing: 0$

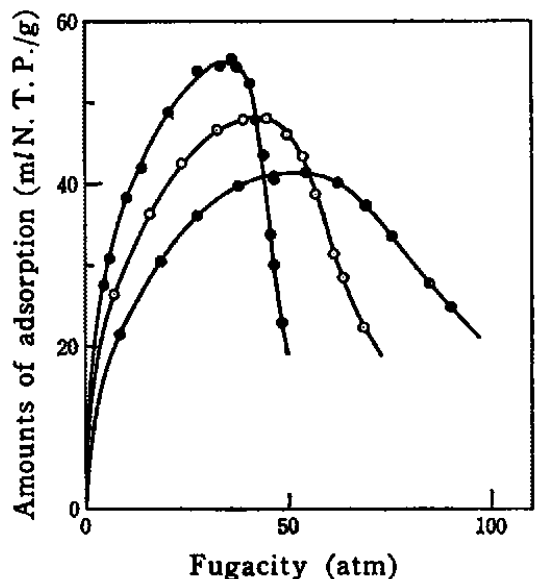

Fig. 9 Adsorption isotherms for ethylene-alumina system

$$
\begin{aligned}
& \text { Temp. }\left({ }^{\circ} \mathrm{C}\right)- \\
& \odot: 75, \bigcirc: 50, \bigcirc: 30
\end{aligned}
$$

差するなど，吸着量一圷力ー温度関係はかなり褯蓶な举動を示した。 な扰吸着平衡到達時間は，メタンの場合 3〜7 分、エタンと土チ レンの場合には 15〜30 分程度であった。

$$
4 \text { 考察 }
$$

\section{1 真の吸着量}

前埌で詳しく述べたように，高圧下での気体の吸着においては， 実湘されるのはいわゆる見かけの吸着量 $\left(\Delta N_{\mathrm{a}}\right)$ であって,これ から真の吸着量 $\left(\Delta N_{\mathrm{t}}\right)$ を求める必要か゚ある。本研究では前回と 同様，吸着相の容積 $V_{\mathrm{g}}$ を吸着媒の細孔容積 $V_{\mathrm{D}}$ で近做し，次式

$$
\Delta N_{\mathrm{t}}=\Delta N_{\mathrm{s}}+d_{\mathrm{g}} \cdot V_{\mathrm{p}}
$$

を使って $\Delta N_{\mathrm{t}}$ を算出した。たたし， $d_{\mathrm{g}}$ は吸着平衡にある気相の 密度である。

さて，以上のよ5にして求めた真の吸着量 $\Delta N_{\mathrm{t}}$ を $f / f_{0}(f:$ 平衡時の気相フガシチー）に対してプロットすれば、これが真の 吸着等温線となり、これに対しては既往の吸着式ないしは吸着理 論の適用を図ることができる。たたし，吸着温度が吸着質の臨果 温度 $T_{\mathrm{c}}$ 以下の場合には， $f_{0}$ は飽和蒸気压に対応するフガシチー であるが，吸着温度が吸着筫の臨界温度以上の場合には館和蒸每 
の存在を考えることが無意味になる。このような場合には，本研 究でも前報に述べた理由によって，吸着温度において砤界密度に 等しい密度を与える压力下でのフガシチーをるって $f_{0}$ とした。

表 1 は以上のようにして求めた真の吸着量が，いかなる吸着式 により統一的に表現できるかを検討した結果である。表中の数字 は，表の最左欄に揭げた吸着式を適用したときの標淮偏差（ml N.T.P./g) を表わす。むた＊印は理論上正の值をとるべき吸着 式中の定数が負值となり，その式の適用が物理的に無意味である ことを示するのである。
まずメタンの場合をみると, Freundlich 式, Frumkin-Temkin 式, Hüttig 式, Langmuir 式, BET 式, Pickett 式のいiずれる 標準偏差が小さく，あまり式による適用性の違いが現われていな い。.Frenkel-Halsey 式はやや琵差が大きくなる。そして強いて 選ら゙と，n=3 の BET 式, あるいは Pickett 式がすべての吸着 媒について偏差が一翻小さいので，適用性が大きいといえる。工 タンの場合には，樶着式の適用性の違いがかなり明白になる。 Frenkel-Halsey 式はかなり偏差が大きく，Langmuir 式は活性 炭への吸着に対し適用性が覀い。Hüttig の式も活性炭への吸羊

Table 1 Standard deviations ( $\mathrm{m} l \mathrm{~N}$. T.P./g) between the calculated absolute amounts of adsorption and the experimental absolute amounts of adsorption

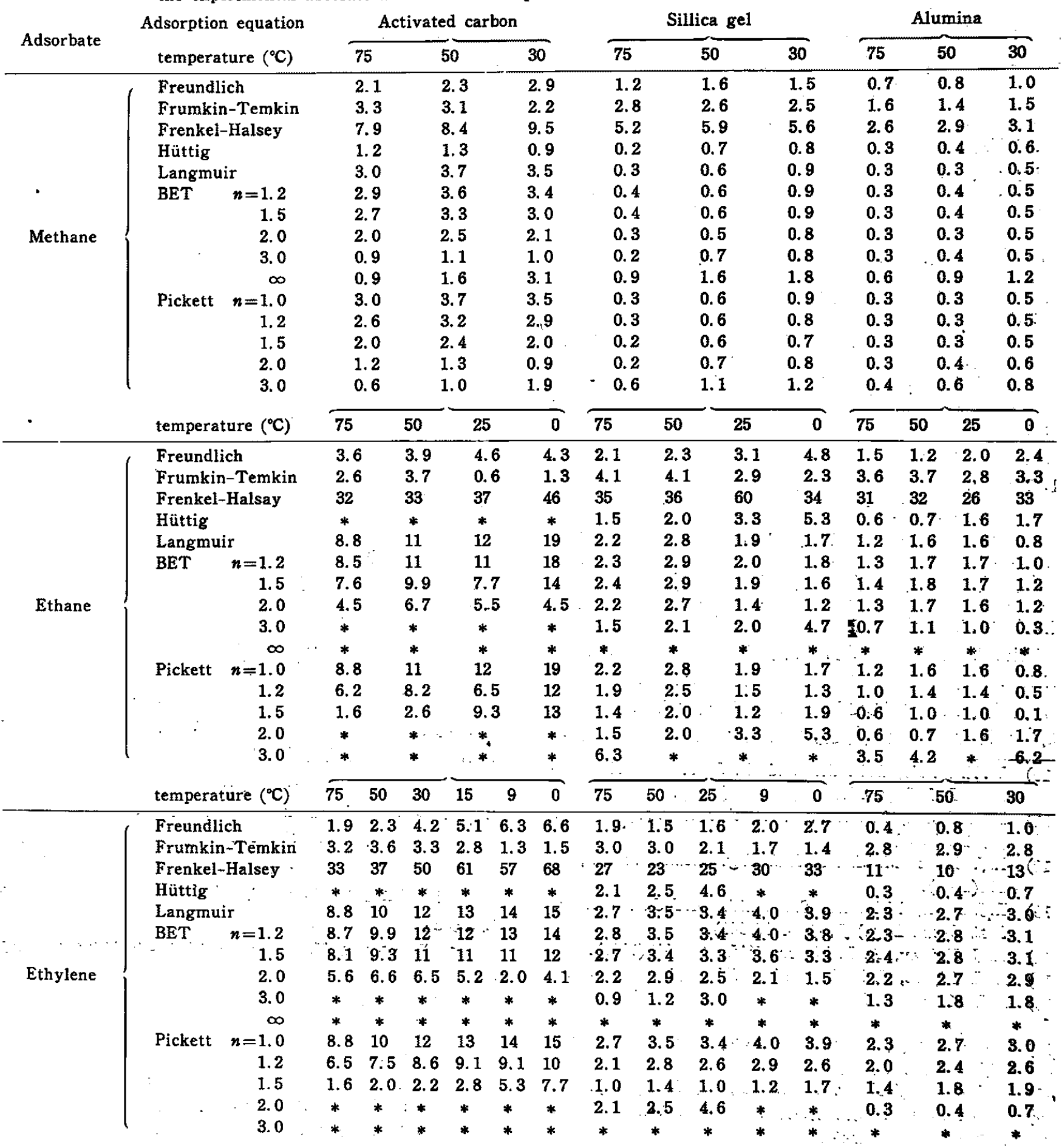


に適用できないし，nが 3 以上の BET 式，Pickett 式はやはり 適用できない。この点, Freundlich 式や Frumkin-Temkin 式 は、ここでみるかぎりはほほ適用できそうにみえる。しかし前報 で述べたように，これらの二つの式は二酸化炭素とか二酸化イオ ウの吸着（ことに活性炭上への）適用性がいちじるしく憅いとい 弓欠点をるっている。それゆえこの場合にす，結局，n=2〜3の BET 式とか, $n=1.5 \sim 2$ の Pickett 式がすっとも妥当であると いうことになる。エチレンの場合る上記エタンと大体同棣な㑯向 である。そして結論的に $n=1.5$ の Pickett 式が一番適用性が大 きく, $n=2$ の BET 式りやや標準偏差が大きいけれどる，一応 の適用性はあると考えられる。そして，ここです Freundlich 式 と Frumin-Temkin 式の適用性怔悪くないが, エタンの場合に 述べたよらな理由からすなわち二酸化炭素と二酸化イオウそれ ぞれに対する適用性に欠けるという点で, 全般的にみると Pickett 式や BET 式よりあ適用性が劣っていると結諭できる。以上，前

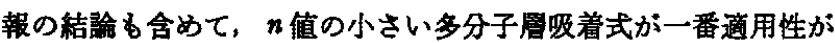
高いと判断できる。

\section{2 吸萧式の一般化}

従来も，固体上への気体の嗳着量を予測しようとするいくつか の研究がなされている。これらは用いられている理論の上から， Polanyi の吸着ポテンシャル理諭炕基礎を粗くもの


いずれす大気圷以下での吸着を対象にしたるのが大部分であって， 真の吸着量亡見かけの吸着量を区別して考える必要のあるような， 高圧下での気体の吸着炕適用することは困難である。

一方，著者らの研究によれば，前報ならびに本報の 4.1 に述へ たように，吸着相の容㭠を吸着媒の基本的性筫の一つである細孔 容積で近侧すると，宾の吸着量が合理的な形17で求められた。そ してその上，本研究と前報の研究で採用した合計 18 組の固体一 気体系のすべてに拈いて，真の吸着量が， $n$ 值の小さい多分子層 吸着式によって統一的に表示できるといら結論が得られている。 この結馀は吸着媒の細孔半径や吸屇質の分子径などから考えて無 理のないすのである。そして以下に述べるように，吸着量の推算 を可能にしようとする試み奶し，かなり有益な知見を与える。

以上のよ5な結果に基づき，以下多分子層吸着式の一つである Pickett の式 ${ }^{18)}$ の吸着量推算への䔔用を検討してみた ${ }^{19)}$ 。多分子 屏吸着式をどの系に対しても適用できるといらことは，この種の 試みにおいてきわめて重要である。さらにこの種の吸着式は,そ

10) W. K. Lewis, E. R. Gilliland, B. Chertow, W. P. Cadogan, Ind. Eng. Chem., 42, 1326(1950).

11) F. D. Maslan, M. Altman, E. R. Aberth, J. Phys. Chem., 57, 106(1953)

12) R. J. Grant, M. Manes, Ind. Eng. Chem. Fundam., 3, 221(1964)

13) R. J. Grant, M. Manes, S. B. Smith, A.I.Ch. E. (Amer. Inst. Chem. Eng.) J., 8, 403(1962).

14) A. J. Kidnay, A. L. Myers, ibid., 12, 981(1966).

15) A. L. Myers, J. M. Prausnity, ibid., 11, 121(1965).

16) A. L. Myers, J. M. Prausnity, Chem. Eng. Sci., 20, 549 (1965).

17）吸着相の容積を適切に評価しないと，真の吸着等温線飞る 極大が現われてしまう。

18) G. Pickett, J. Amer. Chem. Soc., 67, 1958(1945).

19）n-層 BET 式です取り报い方忙余り違わないが，Pickett 式の方がよい結䊬を与える。
れが誘導される過程において，明確な物理的模型を背景にしてい るといらことも有利な点である。

さて, Pickett 式

$$
v=v_{\mathrm{m}} c x\left(1-x^{n}\right) /(1-x)(1-x+c x)
$$

は，単分子層吸着量 $v_{\mathrm{m}}$, 吸着層数 $n$ ，および吸着エネルギーに 関係した定数 $c$ なる三つ心定数を含んでいる。な括，(2)式中で $x=f / f_{0}, \quad v$ 慎の㖟着量 $(\mathrm{m} l \mathrm{~N} . \mathrm{T} . \mathrm{P} . / \mathrm{g})$ である ${ }^{20)}$ 。

前にも述べたように， $f_{0}$ の値は吸着質の物性值 (臨界密度と等 しい密度になる王力下のフガシチー，あるいは飽和蒸気圧に対沈 するフガシチー）から求められる。したがって，Pickett 式の 3 定数が吸着媒ないしは吸着貿の基本的な性質から算出できれば。 吸着量の推算が可能になる。このような趣旨から, Pickett 式中 の定数と吸着媒・暖着質の物性値の関係について，以下に考察を 行なら。

Pickett の式 (2) は

$$
\frac{x\left(1-x^{n}\right)}{v(1-x)}=\frac{1}{v_{\mathrm{m}} c}-\frac{(c-1) x}{v_{\mathrm{m}} c}
$$

のよらに書き換えられる。したがって，いま，なんらかの方法で 吸着居数nの值がきまれば，真の吸着量のデータを代入し，（3） 式の左辺を計算しこれを $x$ に対してプロットすれば踏となり， その勾䢻および切片の值から，他の 2 定数 $v_{\mathrm{m}}$ と $c$ 値が求められ る。このよらなわけで，まずnの值をどのよらにしてきめるかが 問題となる。 $n$ に極端に現実と異なった値を用いると，（3)式の プロットが直線にならなかったり，cが負になったりするから， そのよらな $\boldsymbol{n}$ 値は不道当であるといら判断を下すことができる。 しかし， $n$ 值の小さい変化に対しては，(3)式のプロットの直線 性はあまり敏感に変化せず，さらに実験值には必らず謓差による 多少の散乱があることを考虙すれば，（3）式のプロットの直線性 だけからク値の妥当性を判定することは困難である場合が多い。

以上のような理由から，本研究ではつぎのような方法をとった。 ます吸着分子を半径 $r(\dot{A})$ の球と考え，吸着相ではそれらが最 密充テンして括り，かつ最密充テン面が吸着媒表面に接している

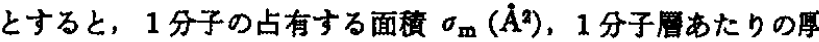
さ $t(\AA)$ は，それぞれ次式

$$
\begin{array}{r}
\sigma_{\mathrm{m}}=2 \sqrt{3} r^{2} \\
t=2 \sqrt{2} r / \sqrt{3}
\end{array}
$$

で与えられる。一方, 吸着媒の比表面積を $\Sigma^{21)}\left(\mathrm{m}^{2} / \mathrm{g}\right)$, 細孔容 積を $V_{\mathrm{p}}(\mathrm{m} l / \mathrm{g})$ とし，吸着媒の細孔に 平行平板モデルを適用す ると，吸着層の更さ $t_{\mathrm{max}}(\dot{A})$ は

$$
t_{\max }=10^{4} \cdot V_{\mathrm{p}} / \Sigma
$$



$$
\begin{gathered}
v_{\mathrm{m}}=22.4 \times 10^{24} \Sigma / N_{\mathrm{sv}} \sigma_{\mathrm{m}} \\
n=t_{\max } / t
\end{gathered}
$$

で与えられることになる。たたし（7）式中の $N_{\mathrm{av}}$ は Avogadro 数である。

さて， $\Sigma$ ならびに $V_{\mathrm{p}}$ の値は，あるきまった吸着某に 対して

20）ここでは慣習にしたがい，真の吸着量として，AN りにvなる記号を使った。

21）ここで使用する比表面樌の值は，Pickett の式を使って求 めたるのとし，吸着モデルの内部に相互矛盾をきたさない ようにした．比表面積の値は，活性炭: $1485 \mathrm{~m}^{2} / \mathrm{g}$ 、シリカ

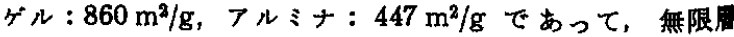
$\mathrm{BET}$ 式を使った值（前報表 1）より多少大きい。 
は一定であるから，このモデルではnを大きくとるを $v_{\mathrm{m}}$ の值す 大きくなる。これに反し（3）式のプロットを使ら方法では，n を大さくすると $v_{\mathrm{m}}$ の値が小さくなる傾向がある。このよらな点 に注目し, 本研究ではnの值を種々変えて吸着そデルから得られ

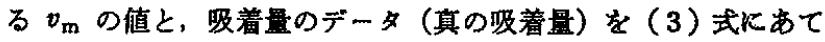
はめて得られる $v_{\mathrm{m}}$ の缙が等しくなるように，一組の定数， $v_{\mathrm{m}}$, n、cをきめた。

つぎに，以上のようにして定められた各定数が吸着媒ないしは 吸着質の物性と、とのような相関性をるつかを検討した。

4.2.1 $v_{\mathrm{m}}, n$ についての相関：上に述べた方法で Pickett 式 の定数を决定する過程に叔いて，吸着分子の半径 $r$ の犆 ${ }^{22)}$ がきま ってくる。一方，吸着分子の充テンモデルから吸着相の密度 $d_{\mathrm{B}}$ $(\mathrm{mol} / \mathrm{l})$ は次式

$$
d_{\mathrm{s}}=10^{27} / 4 \sqrt{2} r^{\mathrm{s}} N_{\mathrm{av}}
$$

で与えられることになる。いま上のよらにしてきまったての値を （9）式に代入し，得られた $d_{\mathrm{g}}$ の値をその吸着質の沸点に和ける 液体密度 $d_{\mathrm{b}}$ で割って無次元化し, 対臨界沮度 $T_{\mathrm{r}}$ に対してプロ ット寸ると図 10 のようになる28)。この図でかかるように，吸着 質の臨界温度以下の低温では $d_{\mathrm{s}}$ の值は飽和液体の密度の値に近 く、高温になるにしたがい臨界密度の值に漸近している。さらに $d_{\mathrm{s}} / d_{\mathrm{b}}-T_{\mathrm{r}}$ 関係は，多少の散乱を無視すれば，吸着媒一吸着質の組 み合わせに関係なく，困中実線で示したように1本の曲線で近似 的に表示できる。

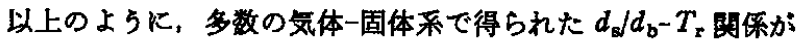
厷い温度範囲にわたり 1 本の曲線で近似できるということは, 吸 着温度を指定すれば図 10 を使って $d_{\mathrm{s}}$ がきめられるということ を意味し，そして，さらに吸着媒の比表面積 $\Sigma$, 細孔容積 $V_{\mathrm{g}}$ の 值に基ついて，(4) （9）の諸式から $v_{\mathrm{m}}$ と $n$ の值がきめられ るといらことにすなる。

4.2.2 定数 $c:$ Pickett の吸着モデルは, 元来 Langmuir 型 単子層吸着を積み重わて多分子層吸着にしたものといえる。そし

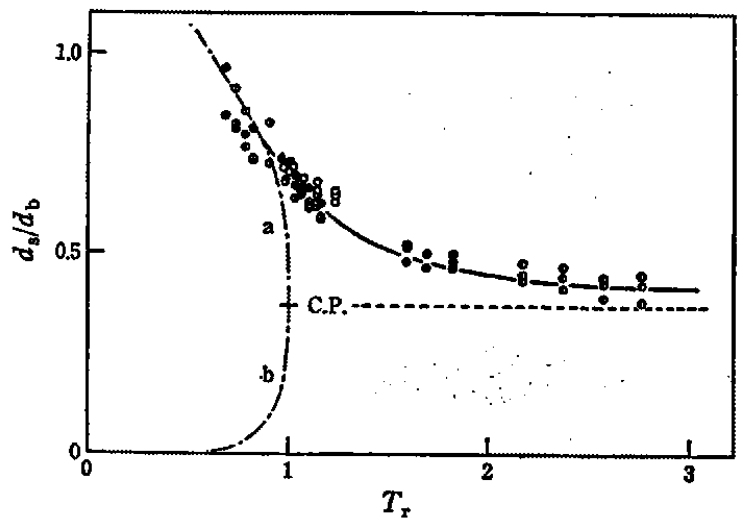

Fig.10 Temperature dependences of the densities of the various adsorbates in the adsorbed phase

$D: \mathrm{N}_{2}, \bigcirc: \mathrm{CH}_{4}, \mathrm{O}: \mathrm{C}_{2} \mathrm{H}_{4}, \odot: \mathrm{CO}_{2}, \mathrm{O}: \mathrm{C}_{2} \mathrm{H}_{6},(1): \mathrm{SO}_{2}$

C. P.: critical point, a : density of saturated liquid, b : density of saturated vapor

22）ここでrの值は，吸着相の容樻を䭒和吸着量（分子数）で 割り，1分子あたりにわりつけられた有奻半径であり，吸

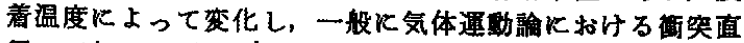
径の $1 / 2$ より大きくなる.

23この図を作辋する場合，前報で述べた吸着データる含めた。
て, 定数 $c$ は第 1 層の吸着平衡定数 $b_{1}$ と，第 2 層以上での吸着 平衡定数 $b_{\mathrm{L}}$ の比であり， $b_{\mathrm{L}}$ は $1 / f_{0}$ に等しいとされている。す なわら

$$
c=b_{1} /\left(1 / f_{0}\right)
$$

したがって，cの値と $f_{0}$ の值から $b_{1}$ の值を求めることができ る。一方, Fowler ${ }^{24)}$ に上れば

$$
b_{1}=\left\{h^{3} /(2 \pi m)^{s / 2}(k T)^{6 / 2}\right\}\left\{f_{\mathrm{a}}(T) / f_{\mathrm{g}}(T)\right\} \exp (\varepsilon / k T)
$$

である。ただし，h は Planck の定数， $\boldsymbol{k}$ は Böltzmann の定数, $m$ 岎子の筫量, 屾吸着ポテンシャルエネルギー，Tは絶対温 度， $f_{\mathrm{a}}, f_{\mathrm{g}}$ はそれぞれ吸着分子および気相分子の内部自由度の分 配䦛数である。

さて，本研究で問題にしているような物理吸着において梳，吸 着にともなっての分子の内部自由度変化は，あまり大きいとは考 えられないから， $f_{\mathrm{a}} \simeq f_{\mathrm{g}}$ とすると（10)，(11）式から

$$
c=f_{0} h^{9} \exp (\varepsilon / k T) /(2 \pi m)^{9 / 2}(k T)^{5 / 2}
$$

が得られる。上式右辺に含まれる諸量のらち，と以外は吸着温度 と吸着質の種類を指定すればきまってしまう。したがって, 吸着 ポテンシャルエネルギー $\varepsilon$ が吸着媒・吸着質の物性值と関係づ られれば, 定数 $c$ の値す吸着媒と吸着筫, 吸着温度を指定すれば きめられることになる。以下には上に述べた目的にそってをない しは $c$ の解析を行なら。

いま，吸着相にある吸着筫の臨界温度を $T_{\text {ead }}$ とし，吸着貿の 三次元的臨界温度を $T_{\mathrm{c}}$ とすれば，簡単な場合には

$$
T_{\mathrm{c}}=\left(\frac{1}{2}\right) T_{\mathrm{ead}}
$$

が成立する ${ }^{26)}$ 。るとる，上式の係数 (1/2) 忙，吸着物筫が二次 元 van der Waals 式にしたがらときに得られるものですっと 複苏な場合 ${ }^{26)}$ るることを考虑して，

$$
T_{\mathrm{c}}=(1 / \alpha) T_{\mathrm{cad}}
$$

と仮定する方が応用範囲が広くなるであろう。ここに，如吸着 相に適用する状態方程式によってきまる一つの定数とする。つぎ に $k T_{\text {cad }} / \varepsilon \equiv T_{\mathrm{cad}}^{*}$ で定莪される量 $T_{\mathrm{cad}}^{*}$ を考光る。巣純な純文 体，あるいは混合無体いずれの塄合にる相互作用ボテンシャルを

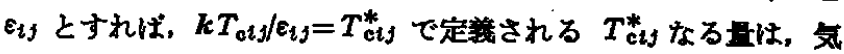
体の種類に夙係のない普遍的な定数であるとみなしらることが知 られている27。たたし上式中添字 $i j$ は同種分子の相互作用を考 えるときは $i=j$ とし，異種分子間の相互作用を考光るときには $i \neq j$ とする。このような気体系で成立する $T_{\mathrm{c} i j}^{*}$ の定数性を固 体一気体系の相互作用，すなわら吸着の場合にる抬張薏用できる と仮定すれば， $T_{\text {cad }}^{*}$ は吸着質の種類に凮係のない定数であると いえることになる。したがって，T觜の定義と（14）式から， $k T_{\mathrm{cad}} / \varepsilon=\alpha k T_{\mathrm{c}} / \varepsilon=\beta$ ( $\beta$ は定数) がなり立つことになる。以上か

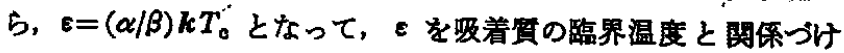
られることになる。そして，この関係を（12）に代入して両辺の 対数をとり整理すると

In $c / f_{0}+(3 / 2) \ln M+(5 / 2)$ ln $T=(\alpha / \beta) T_{r}^{-1}+$ const.

24) R. H. Fowler, E. A. Guggenheim, "Statistical Thermodynamics", Cambridge University Press(1965) p. 421.

25) J. H. deBoer, "The Dynamical Character of Adsorption", Oxford at the Clarendon Press(1953)p. 147.

26）文献 25) の p. 198.

27）たとえば, E. A. Guggenheim, “Mixture”, Oxford at the Clarenton Pres(1952)p. 157. 
が得られる。たたし， $M$ は吸着質の分子量であり，const. は $\boldsymbol{h}$, $k ＼pi ， N_{\mathrm{av}}$ などの普遍的定数のみからなる定数項である。

（15）式をみればわかるように本研究で採用した仮定すななち， $\alpha, \beta$ が定数であることがすし妥当であれば，(15）式の左辺を対 纂界温度 $T_{\mathrm{r}}$ の逆数に対してプロットすれば，そのプロットは固 体一受体系の種類に凰系のない1 本の直線になるはずである。

因 11〜14 は上に述べたよ5な（15）式の検証のためのブロッ トである。ここに，前回の実器値をす含む合計 18 種の固体一気 体系の全体についての検㫌プロットが図 11 である。この図から わかるよ5に，全般的にみて直線性は成立しているといえるか， やや散乱が大きい。このことは前に述べた諸仮定が粗い近似とし ては妥当なすのであることを示す。しかし、二三の試算を行なっ た綃果によると，図 11 に基ついて吸着量を逆算するとかなり大 きな实測值からの偏倚を生ずる。したがって、このままでは吸着 量の推算を行ならことはむずかしい。

以上に述へたよらに，図 11 のプロットの散乱が大きい最大の 理由は，(15)式の誘導において定数 $\alpha, \beta$ を吸着媒の種類にかか わらず一定としたところにあるよらに思われる。（15）式を導くと きに，吸着質の物性は一応 $T_{\mathrm{c}}$ と $\varepsilon$ の間係式 $\varepsilon=(\alpha / \beta) k T_{\mathrm{c}}$ 中に 組みこまれている。にには元来吸着某の性質が反映されているは

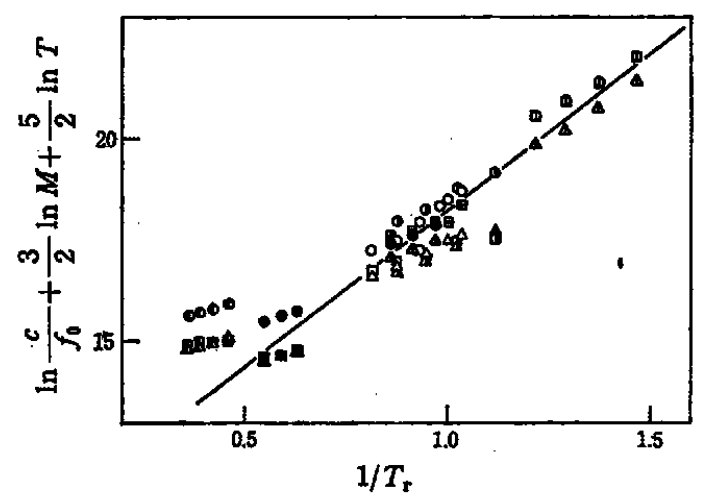

Fig.11 The relation between Pickett's constant $c$ and the reduced temperature for various adsorption systems

$\begin{array}{lcccccc} & \mathrm{N}_{2} & \mathrm{CH}_{4} & \mathrm{C}_{2} \mathrm{H}_{4} & \mathrm{CO}_{2} & \mathrm{C}_{2} \mathrm{H}_{6} & \mathrm{SO}_{2} \\ \text { Activated carbon : } & \square & - & \mathrm{O} & \odot & \bigcirc & \oplus \\ \text { Silicagel : } & \triangle & \Delta & \triangle & \triangle & \Delta & \triangle \\ \text { Alumina : } & \square & \square & \square & \square & \square & \square\end{array}$

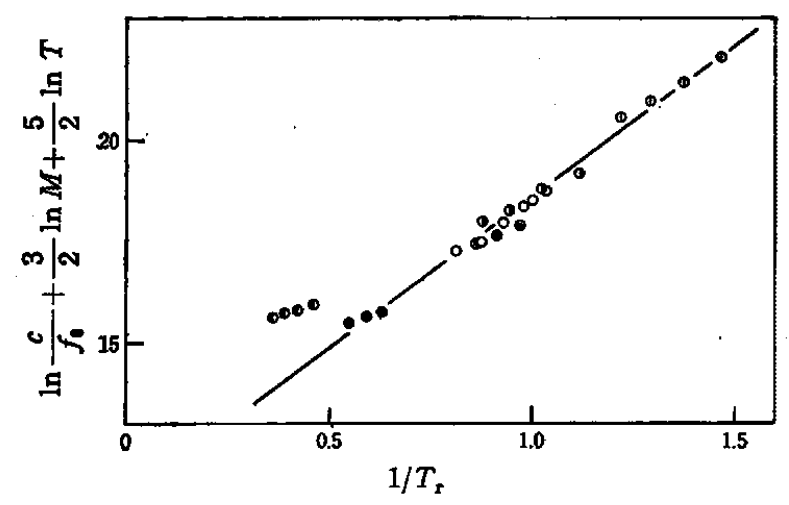

Fig. 12 The relation between the pickett's constant $c$ and the reduced temperature

D: $\mathrm{N}_{2}, \bigcirc: \mathrm{CH}_{4}, \bigcirc: \mathrm{C}_{2} \mathrm{H}_{4}, \odot: \mathrm{CO}_{2}, \odot: \mathrm{C}_{2} \mathrm{H}_{4}$,

(1) : $\mathrm{SO}_{2}$, Adsorption on activated carbon



Fig. 13 The relation between the Pickett's constant $c$ and the reduced temperature D: $\mathrm{N}_{2}, \bigcirc: \mathrm{CH}_{4}, \bigcirc: \mathrm{C}_{2} \mathrm{H}_{4}, \odot: \mathrm{CO}_{2}, \bigcirc: \mathrm{C}_{2} \mathrm{H}_{8}$,
(1): $\mathrm{SO}_{2}$, Adsorption on silicagel

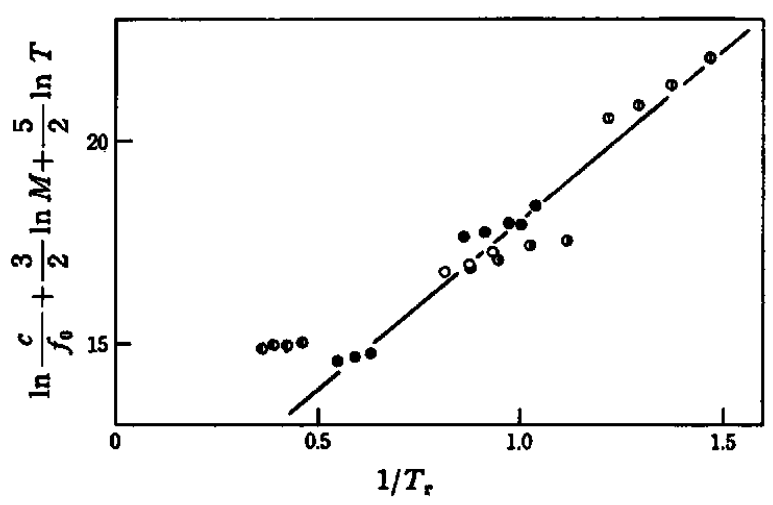

Fig.14 The relation between the Pickett's constant $c$ and the reduced temperature

D : $\mathrm{N}_{2}, \bigcirc: \mathrm{CH}_{4}, \mathrm{O}: \mathrm{C}_{2} \mathrm{H}_{4}, \odot: \mathrm{CO}_{2}, \mathrm{O}: \mathrm{C}_{2} \mathrm{H}_{6}$,

(1) : $\mathrm{SO}_{2}$, Adsorption on alumina

ずであるが,この点が本研究の取り扱いで明確になし得なかった のが，上に述べた偏倚を生む原因であろう。

以上のように考えてくると，あし吸着媒ごとに（15）式のプロ ットを行なえば，図 11 よりはよい結果になるであろうと推測さ れる。このよ5に考えて図 12〜13 を描いた。これらの図をみる と，いずれの吸着媒の場合も空素の点が直線から大きく偏倚して いる。またアルミナの場合，全般的に散乱が目立つが，図 12 の 活性炭の場合などではかなりよい直線プロットが得られている。 窒亲の点が偏倚する理由はいまのところ不明であるが，仮定がき わめて簡単であることを考虑すると，上に述べた結果は吸着量推 算への第 1 歩としては大体满足なるのといえよう。るちろん，曼 着媒の物性値ををと明確に関係づけて図 11 の一般性を高め，空 秦の偏倚などをる消滅させる方向で，取り扱い方法の改善をはか る必要は大いたあるといわねばならない。

\section{3 見かけの吸着量の計算}

いままでに述べてきた本研究の結果を見かけの吸着量の推算に 応用すれば，どの程度の誤差を生ずるかを知っておくことは，今 後の改善を検討する目安を得るといら点からみても意義がある。 このよ5に考元，図 10,12１4 の各線図，吸着質の物性值 $\left(T_{0}\right.$, $\left.f_{0}, M, d_{\mathrm{b}}\right)$, 吸着媒の比表面積 $\Sigma$ ，細孔容積 $V_{\mathrm{p}}$ の值を使い， ままでに述べた手つづきを逆にたどって見かけの偱着量を逆算し た。表 2 は計算值と実測值の平均偏差である。これからわかるよ 
Table 2 Mean deviations( $\%$ ) of the calculated apparent amounts of adsorption from the experimental values

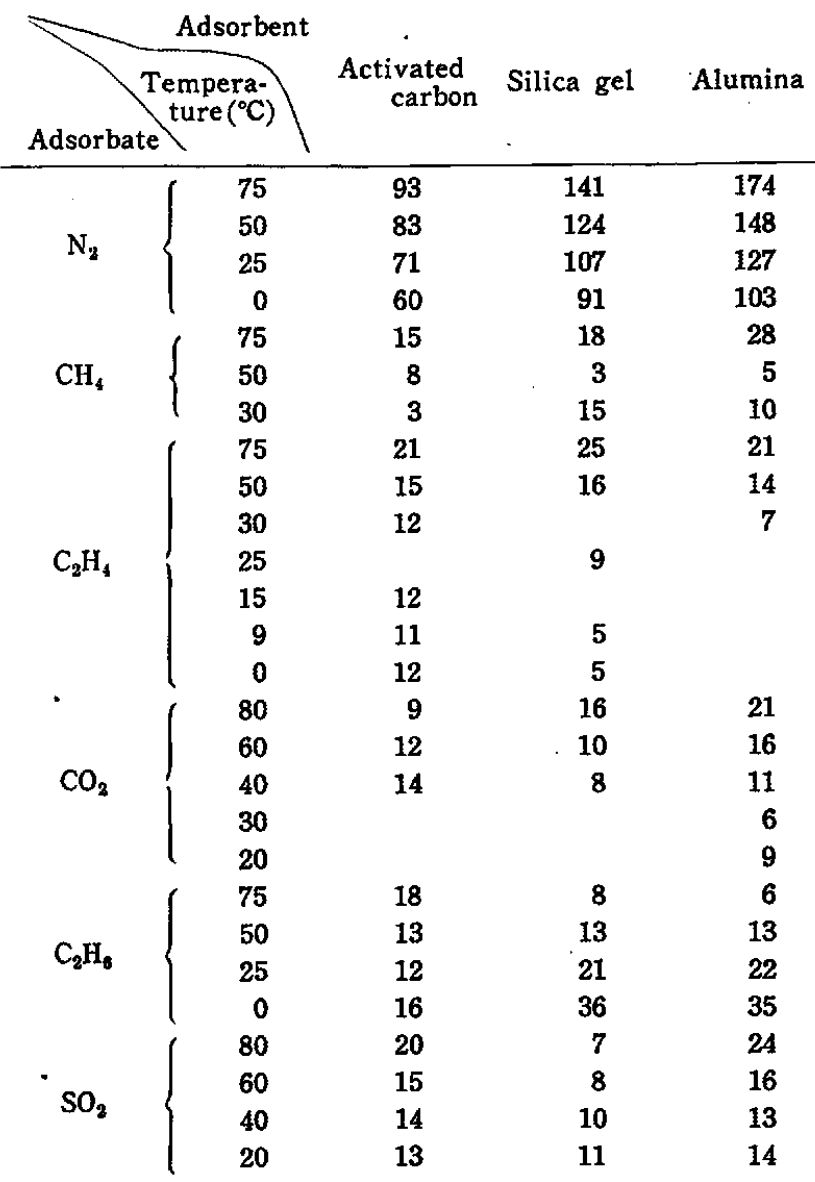

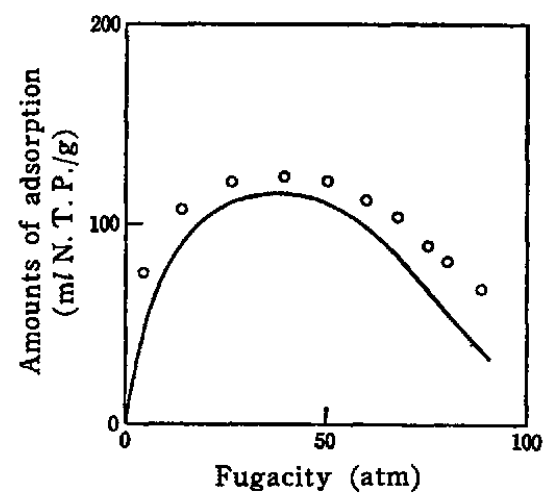

Fig. 15 The apparent amounts of adsorption-comparison of the calculated values with experimental values

$\mathrm{C}_{2} \mathrm{H}_{4}$-activated carbon, - - : calculated,

$O$ : experimental



Fig. 16 The apparent amounts of adsorption-comparison of the calculated values with experimental values

$\mathrm{CO}_{2}$-activated carbon, - : calculated, $\mathrm{O}:$ experimental

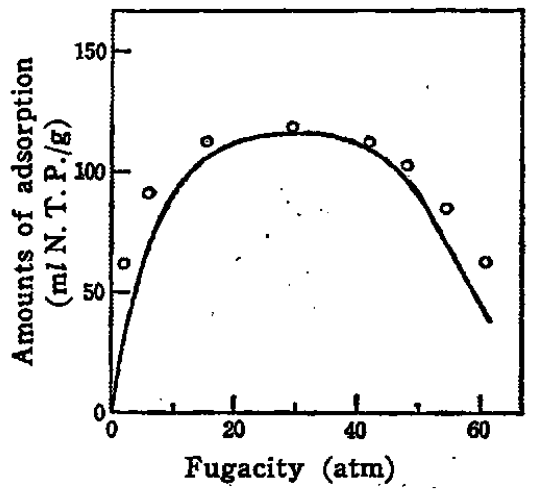

Fig. 17 The apparent amounts of adsorption-comparison of the calculated values with experimental values

$\mathrm{C}_{2} \mathrm{H}_{6}$-activated carbon, - calculated, $O$ : experimental

らに䇪寀の場合はきわめて不一致が大きく、ここでの計算法は吸 着量推算飞は役飞立たない。しかし，他の揚合は実测值との一致 はそれ汪ど悪くない。平均して約 20\% ぐらいの譔差を誌めれば 推算に役立つといえそらである。なお，図 15〜17 は上に述べた ことをかかりやすくするため，二三の吸着等温線について，实湖 值と計算値を比較したるのである。これらの図からかかるように， 実験値との一致恃完全なあのとはいい得ないが, 高圧下の気体の 吸着量を推算する第 1 歩として，また，途中で行なった種々の伖 定の単純なことを考虑に入れると、ほば满足すべき結果ではなか。 ろらかと考えられる。

[東北大学蕃查学位鲙文(博士)]

\section{Measurment and Analysis of High Pressure Gas Adsorptiont \\ Sentaro Ozawa and Yoshisada Ogino \\ Department of Chemical Engineering, Faculty of Engineering, Tohoku: \\ University ; Aramaki, Aoba, Sendai-shi, Japan}

Experiments of gas adsorption at high pressure were carried out with a constant volume type adsorption apparatus. The experimental conditions were as follows; [adsorbents]: activated 
carbon, silica gel, alumina, [adsorbates]: $\mathrm{CH}_{4}, \mathrm{C}_{2} \mathrm{H}_{6}, \mathrm{C}_{2} \mathrm{H}_{4}$, [temperature]: $0 \sim 75^{\circ} \mathrm{C}$, [pressure]: $0.3 \sim 155 \mathrm{~atm}$.

Complicated adsorption isotherms which have their respective maxima at given pressures (and sometimes intercept each other) were observed for almost all cases for $\mathrm{C}_{2} \mathrm{H}_{6}$ and $\mathrm{C}_{2} \mathrm{H}_{4}$.

In all of the gas-solid systems employed in this work, the absolute amounts of adsorptions, which were calculated by assuming that the volume of the adsorbed phase was equal to the pore volume of the adsorbent, were found to be expressed by multilayer adsorption equations with small $n$-values, i.e., BET equation or Pickett's equation with small $n$-values.

Relations of the parameters of Pickett's equation, which fitted well the observed amounts of adsorptions, with the physical properties of the adsorbates and adsorbents were derived, and the resulting correlations among them were used to predict the apparent amounts of adsorptions. It was found that the predicted amounts of adsorptions agree fairly well (with approximately $20 \%$ deviation) with the observed values excepting the adsorption of $\mathrm{N}_{2}$.

† Physical Adsorption of Gases at High Pressures. II.

\title{
低級オレフィンの酸化脱水索芳香族化反応の反応経路
}

(1971. 年 7 月 15 日受理)

\author{
宇田泰三・江 頭誠・清山哲 郎*
}

\begin{abstract}
リン酸ピスマスや酸化スズ系触某上での低級オレフィンの酸化脱水菜芳香族化反応の反応経路を各種 $\mathrm{C}_{3} \sim \mathrm{C}_{8}$ 炭化 水赛の此較から詳細飞検討した。

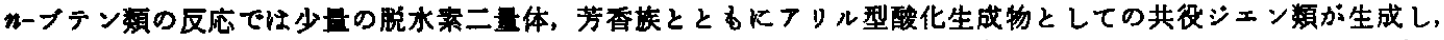

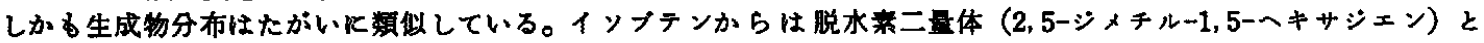

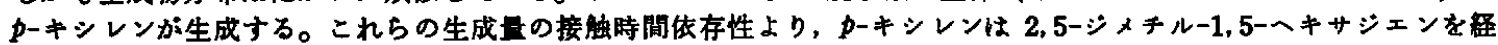
由して生成子ると結論された。1,5-ヘキサシェンからはヘンンヒンとへキサトリェンが生成する。シクロへキサン, シ クロへキセンからはへキサトリエンが副生するが，芳香族化は速くない。しかし 1，3-シクロへキサシェンは選択的

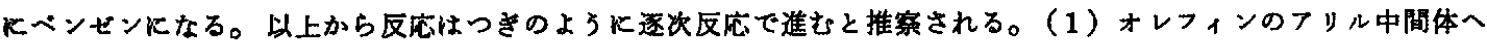



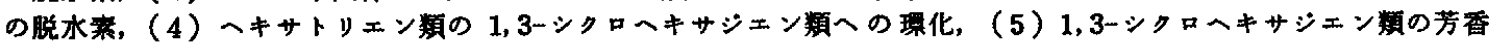
族化。
\end{abstract}

\section{1 菩}

酸化ビスマスー酸化モりブデン系などのソハイオ触媒をはじめ とする多くの金属酸化物触媒上で低級オレフィンを酸化すると， 不飽和アルデヒドや共役ジェンへの部分酸化が起こる。この反応 は工莱的にもかなり利用されており，反応機構や触媒作用の解明 に多くの關心が注がれてきた。そして重水素や重炭素を用いた卜 レーサー実験によって、この反応はアリル型中間体䌊由のいわゆ るアリル型酸化であることが立証されている゙。しかしながら、 金属酸化物上で起こり得る低級オレフィンの部分酸化は上記のア リル型酸化のみではなく，最近新しい二つの反応が見いだされた。 一つは尾㥓) や Buiten8) らによる酸化スズ-酸化モリブデン系触

* 九州大学工学部応用化学教室, 福岡市箱㱦

1) C. R. Adams, T.J. Jennings, J. Catal., 2, 63(1963); H. H. Voge, C. D. Wagner, D. P. Stevenson, ibid., 2, 58(1963).

2) Y. Moro-oka, S. Tan, A. Ozaki, ibid., 12, 291(1968).

3) J. Buiten, ibid., 13, 372(1969).
媒上でのプロと゚レンのアセトンへの酸化であり，すら一つは著者 らがリン酸ビスマス触媒上で見いだしたプロピレンやイソブテン のベンゼン，キシレンあるいは 1,5-ヘキサジエン類への酸化脱 水素二量化芳香族化反応である4。アセトン合成反応は 100 200 ${ }^{\circ} \mathrm{C}$ と比較的低温で起こり, また反応機構の点からもアリル型酸化 とは別の反応に分類できるが，芳香族化反応恃従来のアリル型酸 化とはぼ同一の反灾条件下で起こり，しかもこの反応はリン酸ビ スマス触媒にかきららる特殊な触媒上での反応ではなく，種々の 酸素酸ビスマスや酸化スズ系触媒(), 酸化ビスマスー酸化スズ系依 媒(6)，酸化タリウムや酸化インジウム触媒 ${ }^{7)}$ 上でる生起し，多く の金属酸化物触媒上での一般的な部分酸化反応である。したがっ

4) T. Sakamoto, M. Egashira, T. Seiyama, J. Catal., 16, $407(1970)$.

5) T. Seiyama, M. Egashira, T. Sakamoto, I. Aso, ibid., 投稿中.

6）大段恭二，小川 潵，梅村純郎，山田慶昭，工化，73，842 (1970).

7) D. J. Trimm, L. A. Doerr, Chem. Commun., 1970, 1303. 